\title{
UJI KUALITAS FISIK DAN KANDUNGAN PROTEIN KASAR FERMENTASI JERAMI PADI DENGAN PENAMBAHAN BATANG PISANG DAN DEDAK PADI PADA KONSENTRASI BERBEDA
}

\author{
Test of Physical Quality and Crude Protein Content of Straw Fermentation \\ with Addition of Banana Stems and Rice Bran with Different Concentrations
}

\author{
Idris*, Aminuddin Saade, dan Riski Aulia \\ Politeknik Pembangunan Pertanian Gowa \\ *e-mail: idrisanwar@pertanian.co.id
}

Received: 4 September 2021; Accepted: 10 November 2021; Published: 25 Desember 2021

\begin{abstract}
ABSTRAK
Kajian ini dilaksanakan di kampus Politeknik Pembangunan Pertanian (Polbangtan) Gowa pada bulan mei sampai bulan juli 2021, dan dilaksanakan penyuluhan pada Kelompok Tani Bukkang Raki di Desa Pabentengang Kecematan Bajeng Kabupaten Gowa. Kajian ini bertujuan untuk mengetahui kualitas fisik dan kandungan protein kasar pada fermentasi jerami padi dengan penambahan batang pisang dan dedak padi. Metode kajian disusun berdasarkan rancangan acak lengkap (RAL) yang terdiri dari empat perlakuan dan tiga ulangan sehingga diperoleh 12 sampel. Hasil analisis dengan menggunakan SPSS versi 22. Penambahan dedak padi dapat merubah kualitas fermentasi jerami padi dan batang pisang dengan komposisi jerami padi $40 \%$, batang pisang $40 \%$, dedak padi $20 \%$ dan molasses $10 \mathrm{ml}$ yaitu pada perlakuan P2. Kualitas fisik terdiri dari tekstur dengan nilai rata-rata panelis 2,44\%, warna dengan nilai panelis 3,36\% dan aroma dengan nilai panelis $3,33 \%$. Kandungan fermentasi ini memiliki nilai protein kasar yang paling tertinggi pada perlakuan P2 yaitu 9,26\%.
\end{abstract}

Kata kunci: Fermentasi, silase, jerami padi, batang pisang, dedak padi

\begin{abstract}
This study was conducted at the Gowa Agricultural Development Polytechnic (Polbangtan) campus in May to July 2021, and was conducted counseling at the Bukkang Raki Farmers Group in Pabentengang Village of Bajeng Kbupaten Gowa. This study aims to find out the physical quality and rough protein content in rice straw fermentation with the addition of banana stems and rice bran. The study method was based on a complete randomized design (RAL) consisting of four treatments and three repeats so that 12 samples were obtained. The results of the analysis using SPSS version 22. The addition of rice bran can change the fermentation quality of rice straw and banana stems with a rice straw composition of $40 \%$, banana stems $40 \%$, rice bran $20 \%$ and molasses $10 \mathrm{ml}$, namely on P2 treatment. Physical quality consists of texture with an average panelist value of $2.44 \%$, color with a panelist value of $3.36 \%$ and aroma with a panelist value of $3.33 \%$. This fermentation content has the highest gross protein value in P2 treatment at $9.26 \%$.
\end{abstract}

Keywords: fermentation, silage, rice straw, banana stems, rice bran

\section{PENDAHULUAN}

Sapi potong merupakan ternak ruminansia yang mempunyai empat kompratmen yaitu rumen, reticulum, omasum dan abomasums. Sehingga sistem pencernaan pada sapi dapat memanfaatkan pakan yang mempunyai kandunga serat kasar yang tinggi. Oleh karna itu sapi dapat mengkonsumsi hijauan yang dalam jumlah banyak (Rokhyati, et al. 2016). 
Pakan berfungsi untuk memenuhi kebutuhan ternak baik untuk hidup pokok, pertumbuhan, produksi dan reproduksi. Tiga faktor penting dalam penyediaan hijauan bagi ternak ruminansia adalah kesediaan pakan, kandungan gizi serta kesinambungan sepanjang tahun. Ketersediaan hijauan umumnya berfluktuasi mengikuti pola musim, pada musim penghujan hijauan melimpah sebaliknya terbatas pada musim kemarau (Lado, 2007).

Jerami padi merupakan hasil samping pasca panen tanaman padi yang telah diambil bulir-bulir buahnya. Haryanto et al. (2003) menyebutkan produksi jerami padi dapat mencapai 12-15 ton/ha/panen atau 4-5 ton bahan kering tergantung kondisi lahan dan varietas padi. Selanjutnya menurut Komar (1984) pemanfaatan jerami padi sebagai pakan ternak baru $31 \%$ dari total produksi jerami padi, $62 \%$ dibakar, dan $7 \%$ dimanfaatkan untuk keperluan industri. Pembakaran jerami sangat merugikan karena akan banyak bahan organik termasuk unsur Nitrogen yang hilang serta menggangu lingkungan hidup (Utomo, 2017). Dengan demikian harus kuantitas jerami padi sebagai pakan ternak sangat potensial.

Tanaman pisang merupakan tanaman yang banyak tumbuh di daerah tropis. Indonesia menjadi salah satu negara di daerah tropis yang memiliki keragaman jenis tanaman pisang. Advena (2014) menyatakan bahwa dari total produksi tanaman pisang, 30\% adalah jumlah produksi buah pisang, $60 \%$ produksi batang pisang, dan $10 \%$ adalah produksi daun pisang. Batang tanaman pisang yang tidak terpakai menjadi sampah dan hingga kini belum terdapat penanganan dan teknologi sederhana yang digunakan untuk mendaur ulang bahan ini. Batang pisang merupakan salah satu hasil ikutan pertanian/perkebunan yang dihasilkan dari tanaman pisang yang telah dipanen yang dapat dijadikan sebagai bahan pakan alternatif.

Salah satu limbah yang dapat dimanfaatkan sebagai bahan tambahan pembuatan silase yaitu dedak padi dan batang pisang dengan tujuan dapat meningkatkan kualitas dari silase. Dedak padi merupakan bahan tambahan yang dapat digunakan dalam pembuatan silase sebagai sumber protein. Dedak padi memiliki kandungan protein dan zat gizi yang sangat baik untuk ternak. Sehingga dengan penambahan dedak padi di harapkan dapat meningkatkan kualitas silase jerami padi dan batang pisang dengan kecernaan bahan pakan pada ternak.

Kondisi sekarang ini belum banyak penelitian tentang pemanfaatan limbah jerami padi dengan penambahan batang pisang sebagai pakan. Padahal limbah tersebut mengandung komponen-komponen nutrisi yang bermanfaat bagi ternak. Namun demikian, belum diketahui kualitas fisik dan kandungan protein kasar yang terdapat pada pakan lengkap berbahan utama jerami padi dan batang pisang pada konsentrasi yang berbeda.

\section{METODE PENELITIAN}

\section{Tempat dan Waktu}

Tugas Akhir dilaksanakan pada bulan April - Juni 2021 dimana pengkajian bertempat di kampus Polbangtan Gowa dan penyuluhan dilaksanakan di Kelompok Tani Bukkang Raki di Desa Pabbentengang, Kecamatan Bajeng, Kabupaten Gowa, Provinsi Sulawesi Selatan, Indonesia.

\section{Bahan dan Alat}

Bahan yang digunakan dalam kajian yaitu jerami padi, batang pisang, dedak padi, molases, silo/kantong plastic, karet pengikat, dan kertas label. Alat yang digunakan dalam pelaksanaan kajian yaitu parang, gunting, timbangan, dan gelas ukur, sedangkan alat yang digunakan untuk kegiatan penyuluhan yaitu LPM, sinopsis, leaflet, LCD, Laptop, kamera untuk mendokumentasikan kegiatan dan bahan yang digunakan dalam pelaksanaan demonstrasi cara.

\section{Metode Pelaksanaan}

Kajian ini dilakukan dengan menggunakan rancangan acak lengkap (RAL) dengan 4 perlakuan dan 3 ulangan, sehingga menghasilkan 12 sampel, setiap sampel menggunnakan $5 \mathrm{~kg}$ dengan konsentrasi yang berbeda setiap perlakuan.

$$
\begin{gathered}
\mathrm{P} 0=\begin{array}{c}
\text { Jerami padi } 50 \%+\text { Batang pisang } 50 \% \\
\text { (kontrol) }
\end{array} \\
\mathrm{P} 1=\text { Jerami padi } 45 \%+\text { Batang pisang } 45 \%+ \\
\text { Dedak padi } 10 \% \\
\mathrm{P} 2=\text { Jerami padi } 40 \%+\text { Batang pisang } 40 \%+ \\
\text { Dedak padi } 20 \% \\
\mathrm{P} 3=\text { Jerami padi } 35 \%+\text { Batang pisang } 35 \%+ \\
\text { Dedak padi } 30 \%
\end{gathered}
$$


Perlakuan pada kajian ini didasari dari penelitian yang dilakukan sebelumnya oleh Syahrul. M (2020) menyatakan bahwa penggunaan silase rumput gajah dengan penambahan daun gamal dan ampas tahu memiliki kandungan protein kasar sebanyak $14.06 \%$ dengan konsentrasi yang terbaik yaitu rumput gajah $40 \%$ + daun gamal $40 \%$ + ampas tahu $20 \%$.

\section{Pelaksanaan}

Jerami padi (limbah panen) dicacah kurang lebih $5 \mathrm{~cm}$ menggunakan parang dan batang pisang yang telah ditebang dicaca dengan ukuran 3-5 cm, kemudian di hamparkan selama 1-2 hari (untuk mengurangi kadar air) dibagian lain disiapkan campuran molasess dan air 1-2\% (10 ml molases dengan 0,2-1 L air), ditebarkan secara merata pada campuran cacahan jerami padi, batang pisang dan tambahan dedak padi diaduk secara merata kemudian dimasukkan kedalam silo (kantong plastik ganda) dan ditekan serta divakum untuk mengeluarkan udara yang masih tersisa dalam kantong silo. Selanjutnya kantong silo diikat rapat menggunakan tali rapia dan disimpan diruangan pada tempat yang aman selama 21 hari.

Setelah 21 hari, silo dibuka dan silase diangin-anginkan. Kemudian dilakukan uji organoleptik dan uji proksimat diantaranya kualitas fisik dan protein kasar. Uji organoleptik digunakan untuk memperoleh total rata-rata respon panelis terhadap aroma, tekstur dan warna. Pengujian dengan onganoleptik ini tergolong sangat mudah, praktis dan cepat, karena hanya mengandalkan panca indera panelis. Sedangkan uji proksimat dilakukan untuk mengetahui parameter kandungan protein kasar. Untuk uji organoleptik yang dibutuhkan sebanyak 15 panelis dengan kriteria mahasiswa peternakan, sehat, umur 20 sampai 23 tahun, dan memahami atau mengerti tentang silase jerami padi (pernah membuat silase).

\section{Analisis data}

Kajian ini bertujuan untuk mengetahui ada tidaknya perbedaan nyata setiap perlakuan terhadap kualitas fermentasi jerami padi dengan penambahan batang pisang dan dedak padi, dari hasil uji laboratorium. Metode analisis data yang digunakan dalam kajian ini yaitu data yang diperoleh diolah dengan sidik ragam sesuai dengan Rancangan Acak Lengkap (RAL) dengan bantuan software SPSS versi 22.

\section{Parameter Pengamatan}

Parameter yang diamati dalam penelitian ini adalah uji organoleptik (kualitas fisik) dan uji proksimat (kandungan protein kasar) dilakukan menggunakan uji leboratorium peternakan Universitas Hasanuddin.

\section{Uji organoleptik}

Uji organoleptik digunakan untuk memperoleh total rata-rata respon panelis terhadap warna, aroma, dan tekstur. Pengujian ini hanya mengandalkan panca indra panelis yang memahami dan mengerti tentang silase jerami padi dengan penambahan batang pisang dan dedak padi.

Tabel 1. Cara penilaian organoleptik silase

\begin{tabular}{|c|c|c|}
\hline Kriteria & Karakteristik & Skor \\
\hline \multirow[t]{4}{*}{ Warna } & Coklat kehitaman & 1 \\
\hline & Kecoklatan & 2 \\
\hline & Kuning & 3 \\
\hline & Hijau & 4 \\
\hline \multirow[t]{4}{*}{ Aroma } & Busuk & 1 \\
\hline & Kurang asam & 2 \\
\hline & Asam & 3 \\
\hline & Sangat asam & 4 \\
\hline \multirow{4}{*}{ Tekstur } & Kasar & 1 \\
\hline & Kurang halus & 2 \\
\hline & Agak halus & 3 \\
\hline & halus & 4 \\
\hline
\end{tabular}




\section{Uji proksimat}

Uji proksimat dilakukan untuk mengetahui parameter kandungan protein kasar pada silase jerami padi denga penambahan batang pisang. Analisis Kadar Protein Metode Kjeldahl (AOAC, 2005).

\section{HASIL DAN PEMBAHASAN}

Hasil kajian yang diperoleh berupa uji organoleptik dan uji proksimat yaitu kadar protein kasar pada silase yang difermentasi selama 21 hari. Pengujian silase ini menggunakan 4 kelompok perlakuan konsentrasi bahan berbeda
(P0,P1,P2,P3) dengan 3 kali ulangan. $\mathrm{P} 0=$ jerami padi $50 \%$ + batang pisang $50 \%$ (kontrol), $\mathrm{P} 1=$ jerami padi $45 \%$ + batang pisang $45 \%$ + dedak padi $10 \%, \mathrm{P} 2=$ jerami padi $40 \%+$ batang pisang $40 \%+$ dedak padi $20 \%$, dan P3 = jerami padi $35 \%$ + batang pisang $35 \%$ + dedak padi $30 \%$.

Pengujian organoleptik menggunakan 15 orang panelis dengan kriteria warna, aroma, dan tekstur serta skor 1-4 sesuai karakteristik. Data hasil pengujian organoleptik dianalisis dengan Rancangan Acak Lengkap (RAL) menggunakan aplikasi SPSS 22. Nilai rata-rata hasil uji organoleptik silase kombinasi jerami padi, batang pisang dan dedak padi dapat dilihat pada tabel 2 .

Tabel 2. Rata-rata kualitas fisik silase kombinasi jerami padi, batang pisang, dan dedak padi

\begin{tabular}{cccccc}
\hline No & Kriteria & P0 & P1 & P2 & P3 \\
\hline 1 & Tekstur & $1.80^{\mathrm{a}}$ & $2.36^{\mathrm{b}}$ & $2.44^{\mathrm{c}}$ & $2.33^{\mathrm{b}}$ \\
2 & Warna & $2.71^{\mathrm{a}}$ & $3.18^{\mathrm{b}}$ & $3.36^{\mathrm{c}}$ & $3.16^{\mathrm{b}}$ \\
3 & Aroma & $1.29^{\mathrm{a}}$ & $2.56^{\mathrm{b}}$ & $3.33^{\mathrm{c}}$ & $2.64^{\mathrm{b}}$ \\
\hline
\end{tabular}

Keterangan. P0 : Jerami padi 50\% + batang pisang 50\% (kontrol), P1 : Jerami padi $45 \%$ + batang pisang $45 \%+$ dedak padi $10 \%$, P2 : Jerami padi $40 \%$ + batang pisang $40 \%$ + dedak padi $20 \%$, P3 : Jerami padi $35 \%$ + batang pisang $35 \%$ + dedak padi $30 \%$. Notasi berbeda yang mengikuti nilai rata-rata pada baris sama menunjukkan perbedaan nyata $(\mathrm{P}<0.05)$.

Tabel 2 menunjukkan bahwa nilai ratarata perlakuan silase terbaik pada kriteria tekstur, warna, dan aroma dari keempat perlakuan adalah P2 dengan komposisi jerami padi $40 \%$ + batang pisang $40 \%+$ dedak padi $20 \%$. menunjukkan kriteria dari empat perlakuan yang memperoleh skor tertinggi dari kriteria tekstur adalah P2 skor 2.44 dengan karakteristik agak halus. Skor tertinggi dari kriteria warna adalah P2 skor 3.36 dengan karakteristik hijau. Adapun skor tertinggi dari kriteria aroma adalah P2 skor 3.33 dengan karakteristik asam.

Pengujian kadar protein kasar menggunakan metode Kjeldhal yang dilaksanakan di Laboratorium Fakultas Peternakan Universitas Hasanuddin. Nilai ratarata pengaruh konsentrasi bahan terhadap kadar protein kasar dapat dilihat pada tabel 3.

Tabel 3. Rata-rata hasil uji proksimat

\begin{tabular}{ccccc}
\hline Proksimat & P0 & P1 & P2 & P3 \\
\hline Protein Kasar & $8.66 \%$ & $8.99 \%$ & $9.26 \%$ & $8.57 \%$ \\
\hline
\end{tabular}

Tabel 3 menunjukkan bahwa nilai ratarata pengaruh konsentrasi bahan terhadap kadar protein kasar silase. Nilai rata-rata protein kasar P0 yaitu $8,66 \%, \mathrm{P} 1$ yaitu $8,99 \%, \mathrm{P} 2$ yaitu $9,26 \%$, dan P3 yaitu $8,57 \%$. Nilai kadar protein kasar terendah dari perlakuan P3 dan tertinggi dari perlakuan P2. Hasil analisis sidik ragam menunjukkan konsentrasi bahan silase tidak berpengaruh nyata terhadap kadar protein kasar. Hasil uji lanjut Duncan menunjukkan bahwa semua perlakuan tidak berbeda nyata.

Hasil uji Anova kriteria tekstur menunjukkan bahwa silase kombinasi jerami padi, batang pisang, dan dedak padi berpengaruh 
nyata terhadap tekstur. Hasil uji lanjut Duncan menunjukkan bahwa keempat perlakuan berpengaruh nyata terhadap tekstur yang dihasilkan pada taraf signifikansi 0,05. P0 berbeda nyata dengan P1,P2,P3 sedangkan P1 tidak berbeda nyata dengan P3. Hal ini menunjukkan bahwa silase terbaik pada perlakuan P2 dengan tekstur silase yang agak halus. Hal ini sesuai dengan pernyataan Haustein (2003) bahwa tekstur silase yang baik yaitu lembut dan utuh (lepas). Perubahan tekstur silase yang dihasilkan erat kaitannya dengan aktivitas organisme pembusuk pada proses fermentasi. Perlakuan dengan skor tertinggi yaitu P2, hal ini dikarenakan kadar protein kasar P2 juga memiliki kandungan yang lebih tinggi di banding dengan perlakuan lainnya. Protein kasar merupakan semua zat yang mengandung nitrogen, sedangkan unsur $\mathrm{N}$ akan berdampak pada kemudahan mikroba dalam melonggarkan ikatan jaringan pada jerami. Hal ini sesuai dengan pernyataan Mardiati, dkk (2005) dalam Mayasari, dkk (2015) bahwa substrat jerami akan mudah dicerna oleh mikroba yang mendapat kebutuhan Nitrogen dalam pertumbuhannya.

Hasil uji Anova kriteria warna menunjukkan bahwa silase kombinasi jerami padi, batang pisang, dan dedak padi berpengaruh nyata terhadap warna. Hasil uji lanjut Duncan menunjukkan bahwa keempat perlakuan berpengaruh nyata terhadap warna yang dihasilkan pada taraf signifikansi 0,05. P0 berbeda nyata dengan P1,P2,P3 sedangkan P1 tidak berbeda nyata dengan P3. Hal ini menunjukkan bahwa silase terbaik pada perlakuan P2 dengan warna silase kuning kehijauan. Hal ini sesuai dengan pernyataan Melayu (2010) dalam Christiana (2020) bahwa ciri silase yang baik berwarna hijau atau hijau kecoklatan. Perubahan warna silase yang terjadi erat kaitannya dengan proses respirasi aerobic yang berlangsung selama persediaan oksigen masih ada pada proses fermentasi. Perlakuan dengan skor tertinggi yaitu P2, hal ini dikarenakan kadar protein kasar P2 juga memiliki kandungan yang lebih tinggi di banding dengan perlakuan lainnya. Protein kasar merupakan semua zat yang mengandung nitrogen, sedangkan unsur $\mathrm{N}$ akan berdampak pada perubahan warna silase. Semakin tinggi kadar nitrogen dalam silase maka akan semakin berwarna hijau silase yang dihasilkan. Hal ini sesuai dengan pernyataan Aprintasari, dkk (2012) bahwa perubahan warna silase merupakan efek dari penambahan unsur $\mathrm{N}$.

Hasil uji Anova kriteria aroma menunjukkan bahwa silase kombinasi jerami padi, batang pisang, dan dedak padi berpengaruh nyata terhadap aroma. Hasil uji lanjut Duncan menunjukkan bahwa keempat perlakuan berpengaruh nyata terhadap aroma yang dihasilkan pada taraf signifikansi 0,05. P0 berbeda nyata dengan $\mathrm{P} 1, \mathrm{P} 2, \mathrm{P} 3$ sedangkan $\mathrm{P} 1$ tidak berbeda nyata dengan P3. Hal ini menunjukkan bahwa silase terbaik pada perlakuan P2 dengan aroma silase agak asam. Hal ini sesuai dengan pernyataan Syarifuddin (2001) bahwa aroma silase harum dan terdapat sedikit asam. Perubahan aroma silase erat kaitannya dengan aktivitas oleh bakteri asam laktat selama proses fermentasi. Perlakuan dengan skor tertinggi yaitu $\mathrm{P} 2$, hal ini dikarenakan kadar protein kasar P2 juga memiliki kandungan yang lebih tinggi di banding dengan perlakuan lainnya. Protein kasar merupakan semua zat yang mengandung nitrogen, sedangkan unsur $\mathrm{N}$ digunakan sebagai sumber nutrient bagi pertumbuhan mikroba pembentuk alkohol dan asam pada proses fermentasi. Semakin tinggi kadar nitrogen dalam silase maka efektifitas mikroba dalam menghasilkan asam semakin tinggi. Hal ini sesuai dengan pernyataan Aprintasari, dkk (2012) bahwa prinsipnya fermentasi bertujuan untuk menumbuhkan pertumbuhan mikroba pembentuk alkohol dan asam serta menekan pertumbuhan mikroba yang akan memecah nitrogen.

Berdasarkan hasil uji organoleptik dapat disimpulkan bahwa silase kombinasi jerami padi, batang pisang, dan dedak padi berpengaruh nyata terhadap tekstur, warna, dan aroma pada perlakuan P2 dengan penambahan jerami padi $40 \%$ + batang pisang $40 \%$ + dedak padi $20 \%$. Kualitas silase terbaik pada skor tertinggi memiliki tekstur agak halus, warna kuning kehijauan, dan aroma berbau asam. Hal ini sesuai dengan pernyataan Macauly (2004) bahwa silase yang berkualitas baik memiliki warna hijau kecoklatan dan aroma yang dikeluarkan terasa asam menandakan proses fermentasi dengan baik.

Silase terbaik yang dihasilkan berdasarkan uji proksimat kadar protein kasar yaitu perlakuan P2 9,26\%. Meski rata-rata hasil yang diperoleh berbeda tapi setelah diuji lanjut tidak ada perbedaan. Hail ini sesuai dengan 
pernyataan Pirza (2015) yang menguji bahwa inkubasi menunjukkan perlakuan tidak berpengaruh nyata terhadap silase bahan pakan lengkap berbahan jerami jagung, indigofera dan dedak dengan penambahan molases yang mengalami penurunan pada kandungan protein kasarnya. Menurut Jaelani et al. (2014) kandungan protein dalam silase tidak hanya dipengaruhi lama penyimpanan silase tetapi juga dipengaruhi oleh kadar air, kualitas baku, kandungan protein pada bahan baku serta tingkat keberhasilan pembuatan silase tersebut.

\section{KESIMPULAN}

Kualitas silase jerami padi yang terbaik dari uji kualitas fisik atau uji organoleptik adalah perlakuan P2 yaitu bahan utama jerami padi $40 \%$ + batang pisang $40 \%$ + dedak padi $20 \%$ menghasilkan skor tertinggi memiliki tekstur agak halus yaitu P2 2,44, warna kuning kehijauan yaitu P2 3,36, dan aroma berbau asam yaitu P2 3,33 . Hasil uji proksimat kandungan protein kasar silase jerami padi dengan penambahan batang pisang dan dedak padi yang tertinggi adalah 9,26\% pada perlakuan P2. Hal tersebut tidak terlalu signifikan karena masih pada kisaran yang sama dengan perlakuan P0 yaitu 8,66\%.

\section{DAFTAR PUSTAKA}

AOAC. 2005. Official Methodes Of Analysis Of The Association Of Official Analytical Chemists. Published By The Association Of Official Analytical Chemist. Marlyand.

Aprintasari, R., Sutrisno, C.I., dan Tampoeboelon, B.I.M. 2012. Uji Total Fungi dan Organoleptik pada Jerami Padi dan Jerami Jagung yang Difermentasi dengan Isi Rumen Kerbau. Animal Agriculture Journal: 1 (2) : 311-321.

Christiana.S.M. 2020. Kualitas Fisik Silase Batang Pisang Terhadap Lama Fermentasi yang Berbeda. Jurnal Ilmu Peternakan 1 (2): 40-48.

Dapartemen Pertanian. 1980. Silase Sebagai Maknan Ternak. Departemen Pertanian.
Haryanto, B., I. Inounu, I.G.M. Budiarsana Dan K. Dwiyanto. 2003 Panduan Teknis Integrase Padi-Ternak (Sipt). Departemen Pertanian.

Haustein, S.2003. Evaluating Silage Quality. http://www1.agric.gov.ab.ca. Desember 2011]

Lado, L. 2007. Evaluasi Kualitas Silse Rumput Sudan (Sorghum Sudanense) Pada Penambaha Berbagai Macam Aditif Karbohidrat Mudah Larut, Tesis. Pasca Sarjan Programa Studi Ilmu Peternakan. Umiversitas Gadjah Mada, Yogyakrta.

Macauly, A. 2004. Evaluating Silage quality. http://www1.agric.gov.ab. ca/departement/deptdocs.nsf/all/for4909. html[Feb2008]. 2003. Redefinisi Dan Revitalisasi Penyuluhan Pertanian. Sukohrjo : Puspa. Mayasari, E., Ayuningsih B., dan Hidayat, R. 2015. Pengaruh Penambahan Nitrogen dan Sulfur pada Ensilase Jerami Jagung terhadap Kecernaan Bahan Kering dan Bahan Organik pada Sapi Potong (In Viro). Fakultas Peternakan. Universitas Padjadjaran.

Pirzan , A. W. 2015. Silase Pakan Komplit Berbahan Batang Pisang Sebagai Kambig Jantan Peranakan Etawa. Tesis. Program Pascasarjana Universitas Hasanuddin. Makassar.

Rokhyati, U. A. \& Pateda , S. Y. 2016. Pemanfaatan Gedebok Pisang Sebagai Pakan Alternatif Pada Sapi Potong. Gorontalo. Fakultas Pertanian Universitas Negri Gorontalo.

Syarifuddin, N.A. 2001. Karakteristik dan Persentase Keberhasilan Silase Rumput Gajah pada Berbagai Umur Pemotongan. Fakultas Peternakan Universitas Lambung Mangkurat Banjarbaru, Banjaramasin.

Utomo, R. 2017.Konservasi Hijauan Pakan Dan Peningkatan Kualitas Bahan Pakan Berserat Tinggi. Gadjah Mada University Press. 